REVISTA DE DERECHO UNED, NÚM. 23, 2018

\title{
PERSPECTIVAS DE LA LEY DE SEGUNDA OPORTUNIDAD DE LA PERSONA FÍSICA
}

\author{
PERSPECTIVES OF THE LAW \\ OF SECOND CHANCE FOR THE NATURAL PERSON
}

Luis Montilla ARJona

Abogado. Doctor en Derecho por UNED

Resumen: Transcurridos tres años desde la publicación de la Ley 25/2015, de 28 de julio, de mecanismos de segunda oportunidad, reducción de la carga financiera y otras medidas de orden social, continúa existiendo gran desconocimiento tanto para el profesional como para el profano de las posibilidades que ofrece, y lo que es más importante para el verdadero interesado: la persona física, empresario o no, con sobreendeudamiento y riesgo de insolvencia. Y cuando existen campañas de extensión de su contenido entre los profesionales, para hacer que llegue al destinatario final, son otras leyes y disposiciones de carácter local las que centran la atención aunque por motivos alejados de su finalidad, pero que han enseñado que tras la situación de peligro de «muerte civil» por el estado de insolvencia, existen otras posibilidades, o realidades actuales, para huir del riesgo de caer, hasta ahora irremediablemente, en la economía sumergida.

Palabras clave: Segunda Oportunidad, sobreendeudamiento, insolvencia, deudor persona física, condonación de deuda.

Abstract: Having transcurred three years since the publication of the Law 25/2015, July 28th, about second chance mechanisms, reduction of financial burden and other social order measures, a great ignorance of its possibilities for both profesional and profane continues to exist, and what is most important for the true interested: 
the natural person, entrepreneur or not, with overindebtedness and a risk of insolvency. And when campaigns for the extension of its contents amongst professionals do exist, in order for it to arrive to its final adressee, other laws and dispositions of local character are the ones that focus attention although due to reasons far from their purpose, but which have taught that after the situation of danger of «civil death» by a state of insolvency, other possibilities do exist, or current realities, to evade the risk of falling, hopelessly until now, towards the submerged economy.

Keywords: Second Chance, overindebtedness, insolvency, natural person debtor, debt discharge.

Recepción original: 11/06/2018

Aceptación original: 20/09/2018

Sumario: I. Consideraciones Generales.-II. Naturaleza jurídica y caracteres.-III. Beneficio de la Exoneración del Pasivo Insatisfecho.-IV. Resulta mejorable y conviene mejorarla.-V. ¿Otras propuestas (soluciones) son posibles?: medidas judiciales y extrajudiciales en Catalunya para solventar el sobreendeudamiento del consumidor relacionado con la vivienda habitual, con especial mención de la Ley 24/2015, de 29 de julio, de medidas urgentes para afrontar la emergencia en el ámbito de la vivienda y la pobreza energética, y la Ley 4/2016, de 23 de diciembre, de medidas de protección del derecho a la vivienda de las personas en riesgo de exclusión residencial, ambas suspendidas su vigencia y aplicación en determinados preceptos (los sustantivos) pero que abren camino.-VI. Conclusiones.-VII. Bibliografía.

\section{CONSIDERACIONES GENERALES}

El 29 de julio de 2015 se publicaba en el Boletín Oficial del Estado la Ley 25/2015, de 28 de julio, de mecanismos de segunda oportunidad, reducción de la carga financiera y otras medidas de orden social, completando el proceso de integración en el ordenamiento jurídico español del denominado «mecanismo de segunda oportunidad» dando cobertura a su principal precedente, el Real Decretoley 1/2015, de 27 de febrero, sobre mecanismos de segunda oportunidad, reducción de carga financiera y otras medidas de orden social (en adelante, RDL 1/2015). Sin duda estamos ante una Ley no por esperada menos conocida, y que a fecha de hoy sigue necesitando de recurrentes campañas entre los profesionales para valorar su necesario uso, al considerarse una ley compleja, con instituciones propias 
del Derecho civil, mercantil y procesal, y que en tanto no sea mejor comprendida seguirá sin alcanzar su gran objetivo: evitar que el sobreendeudamiento, por cualquier causa, tenga como consecuencia lo que se ha venido a denominar «muerte civil», y con ella la salida del ciclo económico, con la consecuencia directa del acecho de la economía sumergida.

Esta Ley viene a completar la reforma de la legislación concursal que supuso la Ley 22/2003, de 9 de julio (en adelante, LC), que como en su «Exposición de Motivos I» indica trata de solventar los defectos de la legislación decimonónica en vigor hasta ese momento: «arcaísmo, inadecuación a la realidad social y económica de nuestro tiempo, dispersión, carencia de un sistema armónico, predominio de determinados intereses particulares en detrimento de otros generales y del principio de igualdad de tratamiento de los acreedores, con la consecuencia de soluciones injustas, frecuentemente propiciadas en la práctica por maniobras de mala fe, abusos y simulaciones, que las normas reguladoras de las instituciones concursales no alcanzan a reprimir eficazmente». Pero con ello, no se estaba dando salida a las insolvencias de personas físicas, como lo demuestra la diferencia en el número de concursos presentados entre ambas insolvencias ${ }^{1}$, por no entrar en su comparación en el mismo período con otros países europeos ${ }^{2}$ con una normativa más madura y asentada. Y esto no

${ }^{1}$ De los 1.457 deudores concursados en el primer trimestre DEL 2018, 1.066 son empresas (personas físicas con actividad empresarial y personas jurídicas) y 391 personas físicas sin actividad empresarial, lo que supone el $73,2 \%$ y el $26,8 \%$, respectivamente, del total de deudores.

El número de empresas concursadas disminuye un 3,4\% en el primer trimestre de 2018 respecto al mismo periodo del año pasado.

Según la forma jurídica, el 80,5\% de las empresas concursadas son Sociedades de Responsabilidad Limitada.

El 38,7\% de las empresas concursadas se encuentra en el tramo más bajo de volumen de negocio (hasta 250.000 euros) y son, principalmente, Sociedades de Responsabilidad Limitada (INE, Nota de prensa de 09 de mayo de 2018, www.ine.es).

2 «En España el número de concursos de personas físicas es meramente testimonial: sólo 990 en 2011 a diferencia de lo que ocurre en otros países como Reino Unido (143 871) Francia (56 079 en el mismo año) o Alemania (129.800). Por destacar dos ejemplos, en Holanda, con una población ocho veces menor a la de España, se presentaron catorce veces más procesos de insolvencia (14.344 en 2011). Austria, con una población seis veces menor tiene diez veces más concursos (10.861). En EE.UU. donde el sistema de dicharge o fresh start funciona perfectamente desde hace muchos años y se asume con toda naturalidad, los concursos de persona física han ascendido nada menos que a 15.000 .000 entre 1997 y 2007 (a una media de 1.500.000 concursos por año), 884.956 en 2014 mientras que en España este año pasado han sido tan solo 646 los concursos instados por personas físicas».

VIGUER SOLER, P.L., "Análisis crítico del RDL 1/2015 sobre «segunda oportunidad»: expectativas, luces y sombras», Diario La Ley n. ${ }^{\circ}$ 8592, Sección Doctrina, 29-07-2015, Ref. D-304 (LA LEY 5003/2015).

(C) UNED. Revista de Derecho UNED, núm. 23, 2018 
deja de sorprender cuando el nombre elegido para el procedimiento único es el de "concurso", expresión acuñada por los tratadistas españoles del siglo $\mathrm{XVII}^{3}$ en alusión a la concurrencia de acreedores sobre el patrimonio del deudor, pasando al vocabulario jurídico procesal europeo, y que sin embargo, contentos con nuestra historia jurídica, nos ha llevado más de un siglo adaptarlo a la realidad, superando la diversidad de instituciones concursales para comerciantes y no comerciantes, tratando de eliminar el carácter represivo de la insolvencia mercantil, aunque en el ADN jurídico está costando el cambio de mentalidad, como lo demuestra el bajo número de empresas que continúan después de un proceso de este tipo ${ }^{4}$.

$\mathrm{Y}$ en el supuesto que va a centrar este estudio, la persona física y el empresario individual, no ha resultado eficiente, como demuestra el bajo número de convenios que se alcanzan ${ }^{5}$, y el hecho de que las que devienen principales deudas de la persona física, el crédito hipotecario y el crédito público, quedan fuera del concurso (con matizaciones que veremos). No por ello no era necesario; habitual era la crítica al promulgarse la Ley 22/2003, LC, sobre la posibilidad de que las deudas no saldadas de las empresas devenían incobrables con la conclusión del concurso (art. 178.3 LC) y el cierre de la empresa (persona jurídica), en tanto que el deudor persona física por el principio de responsabilidad patrimonial universal del art. 1911 CC mantenía la deuda no saldada a la conclusión del concurso ${ }^{6}$. Y resultaba complejo en nuestra cultura jurídica liberal al amparo del Código Civil de 1889 plantearnos la consistencia del principio de responsabilidad patrimonial universal, que suponía hacer caer en el asilamiento social al deudor, perseguido sine die por acreedores, condenado al ostracismo social, con escasas posibilidades de volver al ciclo económico, por no poder tener a su nombre ni una cuenta

${ }^{3}$ Fundamentalmente Amador Rodríguez (Tractatur de concursu, 1616) y Francisco Salgado de Somoza (Labyrinthus creditorum concurrentium, 1646)

${ }^{4} \mathrm{El}$ número de empresas que cierran sus puertas tras entrar en quiebra se ha reducido sobremanera, desde el 93\% que se registraba en 2004 (al primer año de la Ley Concursal) hasta el 56\% del ejercicio pasado, según la consultora Informa, especializada en insolvencias. No es que el resto hayan logrado salir del concurso - apenas el 1\% lo hicieron en 2016 y el mejor dato de la serie histórica solo llegó al 3,5\% (2013)_, aunque al menos un tercio sobreviven en esa situación, el 36,8\% en 2016, diez veces más que en 2005 (solo el 3\%). (www.economista.es, 28.05.2017).

${ }^{5}$ De los 1457 concursos presentados en el 1r. Trimestre del 2018, solo 4 presentaron propuesta anticipada de convenio. (INE, Nota de prensa de 09 de mayo de 2018, www.ine.es).

${ }^{6}$ Art. 51.1 CE impone a los poderes públicos «el deber de garantizar la defensa de los consumidores y usuarios, protegiendo, mediante procedimientos eficaces, la seguridad, la salud y los legítimos intereses económicos de los mismos.». 
bancaria. En muchos casos la mala suerte convertida en «delito» y el sistema con una rémora por la falta de respuesta.

No es que hasta el año 2015 no se hubiera tratado el tema sino que el acierto fue de resultado escaso. Con anterioridad a la promulgación de la LC del 2003 se presentó una Proposición de Ley del Grupo Parlamentario Socialista ${ }^{7}$ con el objetivo de cubrir el vacío legal en el tratamiento de la insolvencia de las personas físicas, creando para ello un sistema específico de prevención y protección extrajudicial de los consumidores ${ }^{8}$ centrado en la figura de los que debían denominarse Centros de Arbitraje de Sobreendeudamiento ${ }^{9}$, con la finalidad de obtener un compromiso amistoso de pago entre el deudor y sus acreedores elaborado por una Junta Arbitral. Si fracasaba esta solución extrajudicial el proceso pasaba a sede judicial. Esta iniciativa no prosperó. La segunda Proposición fue elaborada el 12 de noviembre de $2004^{10}$ por el Grupo Parlamentario catalán Convergència i Unió, con una estructura muy similar a esta socialista y con idéntico final. Por hacer mención el RDL 8/2011, de reforma de la LEC, elevó el limite de inembargabilidad a deudores que hubieran perdido su vivienda y elevó el límite de adjudicación de primera vivienda vía subasta al 60\%; el RDL 6/2012 aprobó el Código de Buenas Prácticas Bancarias, aunque por los límites condicionaba su aplicación y de ahí su escasa repercusión; en el mismo año el RDL 27/2012 estableció la suspensión de lanzamientos de vivienda habitual durante 2 años; la Ley 1/2013, consecuencia de la STJUE de 14 de marzo de 2013, modificó el proceso de ejecución hipotecaria; y la Ley 14/2013, Ley de Emprendedores que trató de incluir los de-

7 BOCG, Congreso de los Diputados, Serie B, 336-1, de 9 de mayo de 2003, Proposición de Ley 122/000295.

${ }^{8} \mathrm{El}$ ordenamiento jurídico español cuenta con un concepto jurídico de consumidor, proporcionado por el antiguo art. 1 LGDCU (modificado por la Ley 44/2006, de 29 de diciembre, de mejora de la protección de los consumidores y usuarios y que recoge las principales exigencias de la Directiva 93/13/CEE, impulsada a consecuencia de la STJCE de 9 de septiembre de 2004, que condenó a España por transposición incorrecta de determinados aspectos de aquélla, y que tras la aprobación del RDL 1/2007, Texto Refundido LGDCU, se corresponde al art. 3, que aunque circunscrito a los efectos de esta Ley, viene a disponer básicamente que se consideran consumidores las personas físicas o jurídicas que adquieren, utilizan o disfrutan como destinatarios finales una serie de bienes, servicios y productos.

9 RIBÓN SEISDEDOS, «El sobreendeudamiento en España: tutela judicial y protección legislativa», Informe realizado pro el CEACCU en diciembre de 2005, pag.17. En él viene a defender que no existe expresión en derecho positivo que nos proporcione un concepto jurídico de la que ha de entenderse por sobreendeudamiento de los consumidores. Su falta de tipicidad lo convierte en una cuestión de política legislativa, de acotamiento por el legislador en normas concretas.

${ }_{10}$ BOCG, Senado, Serie III, A, 14 (2) de 12 de noviembre de 2004, Proposición de Ley 622/000012. 
nominados mecanismos de fresh start ${ }^{11}$, y que abrió camino a la figura del emprendedor de responsabilidad limitada (art. 7 a 11). En octubre del 2013 la Defensora del Pueblo emite un Informe que llevaba por nombre "Crisis económica e insolvencia personal», y organismos como el Fondo Monetario Internacional, en 7 de julio de 2014 ${ }^{12}$, la Unión Europea, en Recomendación de 12 de marzo de $2014^{13}$, el Dictamen del Comité Económico y Social Europeo sobre "Protección de los consumidores y tratamiento adecuado del sobreendeudamiento para evitar la exclusión social» ${ }^{14}$ y las conclusiones de la XXIV Reunión de los Jueces Decanos de España, en Valencia ${ }^{15}$, pusieron sobre la mesa la necesidad del tratamiento especializado de las situaciones de insolvencia de las personas físicas. Y sobre todo, quedaba de manifiesto, que era un problema global, máxime en plena crisis socio-económica con endeudamiento altísimo de familias y empresas, con las consecuencias que hemos padecido de paro, precariedad, pérdidas económicas y morales.

La respuesta en España sin duda parte de la segunda Ley de apoyo a los emprendedores, Ley 14/2013, de 27 de septiembre, que vino a incorporar a la Ley Concursal un nuevo Título X bajo el epígrafe «El acuerdo extrajudicial de pagos» (arts. 231 a 242). Figura sin precedentes en nuestro ordenamiento jurídico ${ }^{16}$ pero no por ello ausente de iniciativas como la Propuesta de Anteproyecto de Ley Con-

${ }^{11}$ La configuración del concurso en Estados Unidos parte de la idea de comienzo de cero o "fresh start», persiguiendo la recuperación patrimonial del deudor, concederle una segunda oportunidad, en SERRANO GÓMEZ, Eduardo y otros, "Sistemas de tratamiento de la insolvencia de la persona física», Cap. I, pág. 36, CUENA CASAS, Matilde (dra.), en Familia y concurso de acreedores, Thomson Reuters (Aranzadi), Pamplona, 2010.

12 Dicho informe consideró excesivamente dura la legislación civil y mercantil española y recomendaba estudiar a fondo la aplicación del fresh start y generar en determinados supuestos para el deudor una segunda oportunidad. Y es que la perspectiva de una rendición de cuentas perpetua desincentivaba la iniciativa empresarial y alimentaba la economía sumergida.

${ }_{13}$ Se refería especialmente a las pequeñas empresas y el fracaso empresarial. Reitera el término "segunda oportunidad», y señala que "el objetivo de la presente Recomendación es garantizar que las empresas viables con dificultades financieras, cualquiera que sea su ubicación en la Unión, tengan acceso a unos marcos nacionales de insolvencia que les permitan reestructurarse en una fase temprana con el fin de prevenir la insolvencia y, por lo tanto, maximizar su valor total para los acreedores, los empleados y los propietarios, así como para el conjunto de la economía.».

${ }^{14}$ Se centraba en el sobreendeudamiento de los consumidores, y trataba de dar una definición común del sobreendeudamiento, incidiéndose en elementos de sencillez procesal, y la lucha contra los intereses abusivos, y la posibilidad de educación en la búsqueda de un crédito responsable.

15 www.poderjudicial.es

16 ROJO, Ángel, «La reforma del derecho concursal español» (Rojo, dr.), Ed. Marcial Pons, Madrid-Barcelona, 2003, pág. 107 y ss. 
cursal de 1995, donde ya se preveía un procedimiento de suspensión de pagos para el deudor que no hubiera incumplido aun sus obligaciones o con bajo incumplimiento o repercusión por importe. Dicha regulación es actualizada con el RDL 1/2015, de 27 de febrero, de mecanismo de segunda oportunidad, reducción de carga financiera y otras medidas de orden social ${ }^{17}$, y por la subsiguiente Ley $25 / 2015$, de 28 de julio, de mecanismo de segunda oportunidad, y se ataca en un doble sentido: regulando un proceso específico pero no aislado para el concurso de personas físicas e introduciendo un verdadero mecanismo de segunda oportunidad, que evitara la insolvencia perseguible sine die, con vistas en las recomendaciones de organismos internacionales y la evidencia de resultado en otras legislaciones europeas. Y además se debía hacer extensivo a los pequeños empresarios que debieron soportar con virulencia la crisis del momento.

\section{NATURALEZA JURÍDICA Y CARACTERES}

Entrando en el concepto de «segunda oportunidad» podemos definirla por sus objetivos: posibilidad que se ofrece al deudor (de buena $\mathrm{fe}^{18}$ ) de negociar con sus acreedores para conseguir extinguir

17 Señala en su Exposición de Motivos que su objetivo es "que una persona física, a pesar del fracaso económico, empresarial o personal, tenga la posibilidad de encarrilar nuevamente su vida e incluso arriesgar a nuevas iniciativas, sin tener que arrastrar indefinidamente una losa de deuda que nunca podrá satisfacer».

${ }^{18}$ Los requisitos para ser considerado de «buena fe» se establecen en al propia LC: $\left.1^{\circ}{ }^{\circ}\right)$ Que el concurso no haya sido declarado culpable. Pero incluso en ese supuesto, aunque haya sido declarado culpable por aplicación del artículo 165.1.1. ${ }^{\circ}$ LC cuando el deudor o, en su caso, sus representantes legales, administradores o liquidadores, hubieran incumplido el deber de solicitar la declaración del concurso, el juez podrá conceder el beneficio y siempre que no se apreciare dolo o culpa grave del deudor. 2. $^{\circ}$ ) Que el deudor no haya sido condenado en sentencia firme por delitos contra el patrimonio, contra el orden socioeconómico, de falsedad documental, contra la Hacienda Pública y la Seguridad Social o contra los derechos de los trabajadores en los 10 años anteriores a la declaración de concurso. $\left.3 .^{\circ}\right)$ Que el deudor haya satisfecho en su integridad los créditos contra la masa (como son los salarios, las costas y gastos judiciales de la solicitud y declaración del concurso, etc...) y los créditos concursales privilegiados (entre los que se encuentran los hipotecarios). $4 .^{\circ}$ ) Que en el caso de no haber intentado un acuerdo extrajudicial de pagos previo, haya satisfecho al menos, el 25 por ciento del importe de los créditos concursales ordinarios. 5. $^{\circ}$ ) Que alternativamente a este anterior requisito, acepte someterse a un plan de pagos, que cumpla las obligaciones de colaboración e información del artículo 42 LC, que no haya obtenido este beneficio de exoneración en los últimos 10 años, que no haya rechazado una oferta de empleo adecuada a su capacidad dentro de los 4 años anteriores a la declaración de concurso, o que en la solicitud de exoneración, acepte de forma expresa, que la obtención de este beneficio se hará constar en la sección especial del Registro Público Concursal por un plazo de 5 años, teniendo acceso a esta sección las personas que tengan interés legítimo 
las deudas a través de un nuevo marco regulatorio (convenio), o por liquidación de su patrimonio. FERNÁNDEZ SEIJO ${ }^{19}$ aclara que no se trata precisamente de un "premio», porque el deudor liquida y «pierde» su patrimonio, siendo susceptible de ser recuperado para el tráfico económico y jurídico, sacándole de la economía sumergida.

En este contexto y con este devenir histórico, debemos preguntarnos qué nos aportan este RDL 1/2015 y la Ley 25/2015. Se parte del concepto de "deudor de buena fe», que la propia Ley delimita (ver nota 18), el cual trata facultativamente de alcanzar un acuerdo extrajudicial o bien es abocado al propio concurso (consecutivo) con la finalidad de llegar a la exoneración total del "pasivo insatisfecho». Se trata de buscar una segunda oportunidad. Analicemos su desarrollo.

\section{a) Requisitos subjetivos}

Conforme al art. 231 LC puede acudir a la mediación extrajudicial la persona natural, empresario o no, que se encuentre en situación de insolvencia ${ }^{20}$, o que prevea el incumplimiento de sus obligaciones económicas, siempre que la estimación inicial del pasivo no supere lo cinco millones de euros. Esta apreciación es extensible a personas jurídicas cuyo balance tenga cabida en las estipulaciones del art. 190 LC (pasivo y patrimonio inferior a cinco millones de euros, y menos de 50 acreedores, y puedan satisfacer los gastos del proceso). En el supuesto de persona física empresario ${ }^{21}$ también deberá aportar balance que dé cobertura a la valoración inicial. Preci-

en averiguar la situación del deudor, quienes realicen una oferta de crédito o de cualquier otra entrega de bienes o prestación de servicios, que tenga que ser remunerada o devuelta por éste y que esté condicionada a su solvencia, así como las Administraciones Públicas y órganos jurisdiccionales habilitados legalmente para recabar la información necesaria para el ejercicio de sus funciones.

19 FERNÁNDEZ SEIJO, José M., "Aspectos Concursales de la Ley de Segunda Oportunidad», Diario La ley, n. ${ }^{\circ}$ 8500, sección doctrina, 13 marzo 2015.

${ }^{20}$ ORDUÑA MORENO, "La insolvencia: análisis de su concepto y concreción de su régimen jurídico», Tirant Lo Blanch, Valencia, 1994. Obra extensa donde en su pág. 51 afirma que la nota esencial o núcleo duro del significado de la insolvencia no es otro que el perjuicio del derecho de crédito en orden a la responsabilidad patrimonial del deudor, puesto que la insolvencia se presenta como un auténtico perjuicio del derecho de crédito que frustra la posible satisfacción del interés patrimonial del acreedor inherente al crédito.

${ }^{21}$ La ley considera empresarios no sólo aquellos que tuvieran tal consideración según la legislación mercantil, sino también aquellos que ejerzan actividades profesionales o que así deban ser considerados de conformidad con la legislación de la Seguridad Social, los autónomos. 
samente la presencia de personas físicas define la competencia objetiva de los Juzgados de Primera Instancia (art. 85.3 LOPJ).

En sentido negativo, no pueden solicitar (art. 231.3 LC) un acuerdo extrajudicial de pagos (en adelante AEP): 1) quienes hayan sido condenados por sentencia firme en los diez años anteriores a la declaración de concurso por delito contra el patrimonio, el orden socioeconómico, falsedad documental, contra la Hacienda Pública, la Seguridad Social o contra los derechos de los trabajadores.; 2) quienes en los últimos cinco años hubieran alcanzado un AEP con sus acreedores, hubieran obtenido la homologación judicial de un acuerdo de refinanciación o hubieran sido declaradas en concurso de acreedores ${ }^{22}$; 3) quienes ya estén negociando un acuerdo de refinanciación o cuya solicitud de concurso hubiera sido admitida a trámite (art. 232.4 LC); 4) las entidades aseguradoras o reaseguradoras (art. 232.5 LC).

\section{b) Requisitos objetivos}

$\mathrm{El}$ art. $2 \mathrm{LC}^{23}$ tiene su reflejo en el art. $231 \mathrm{LC}$ al exigir la «insolvencia» como presupuesto objetivo, que se suaviza en el caso de la persona física al posibilitar «que prevea que no podrá cumplir regularmente con sus obligaciones» como requisito. Observo acertado que no se aluda a las causas de imposibilidad de pago, eliminando la distinción entre insolvencia activa (desacierto) e insolvencia pasiva (desventura).

\section{c) Procedimiento}

Regulado en los arts. 232 a 242 LC, prevé la SOLICITUD ente el Registrador Mercantil del domicilio del solicitante o ante las Cámaras de Comercio que hayan asumido funciones de mediación, para el supuesto de empresario o persona jurídica, reservándose el Notario del domicilio del deudor para el resto de solicitantes. El art. 232.2 LC prevé la utilización de un formulario normalizado (de hecho prevé el inicio por instancia suscrita por el deudor en el caso de per-

\footnotetext{
${ }^{22}$ Requisito exigible desde el 30 de julio de 2016 según la D.T. 1. ${ }^{\text {a }} 5$ de la Ley $25 / 2015$.

${ }^{23}$ SUÁREZ-LLANOS GÓMEZ, «El presupuesto objetivo del concurso: el estado de insolvencia». Las claves de la Ley concursal, Navarra, Aranzadi, 2005 (Dr. QUINTANA CARLOS, BONET NAVARRO, GARCÍA-CRUCE GONZÁLEZ). En su pág. 41 cree muy acertado que la LC no aluda al porqué de la imposibilidad por parte del deudor de cumplir regularmente con su obligaciones exigibles.
} 
sonas físicas), haciéndose constar el activo de que dispone y su liquidez, así como lo bienes y derechos que mantiene, sus ingresos regulares, y el pasivo que adeuda, con expresión de la cuantía y vencimiento, así como las posibles garantías prestadas, contratos vigentes y relación de gastos mensuales. El inicio debe comunicarse (sólo es comunicado) al Juzgado competente para el concurso y al Registro Público Concursal.

Seguidamente se realiza el NOMBRAMIENTO DEL MEDIADOR CONCURSAL (art. 231.1 LC), que deberá reunir las condiciones establecidas en la Ley 5/2012, de 6 de julio, de mediación en asuntos civiles y mercantiles, desarrolladas en el RD 980/2013, de 13 de diciembre, centradas en la exigencia de titulación específica, formación inicial y continuada, y la exigencia de seguro obligatorio de responsabilidad. Para mayor concreción el art. 27 LC habla de abogado, economista, titulado mercantil o auditor de cuentas, con cinco años de experiencia, con formación inicial y continuada específica. El actual art. 233.3 LC contempla la posibilidad de que la función la pueda asumir la Cámara de Comercio correspondiente, cuando la solicitud se presente ante la misma, y cuando, conforme a la Ley 4/2014, de 1 de abril, Básica de las Cámaras Oficiales de Comercio, Industria y Navegación, la solicitud se presente ante éstas. También contempla la LC que el Notario pueda continuar por sí las gestiones para el supuesto de persona física no empresario (art. 242 bis). El nombramiento se hará entre los que figuren en la lista oficial elaborada por el Ministerio de Justicia, y su retribución está prevista en el RD 1860/2004, gozando de reducciones del 70\% para la persona física no empresario, 50\% para el empresario individual, y del 30\% para persona jurídica (D.A. 2. ${ }^{a}$ RDL 1/2015). No obstante la designación debe contar con la aceptación del cargo por el mediador. Como singularidad en el caso de persona física no empresario o profesional, las actuaciones notariales o registrales del inicio del procedimiento extrajudicial de nombramiento de mediador (art. 233 LC) no devenga retribución arancelaria.

Aceptado el cargo por el mediador (o en caso el Registrador Mercantil, Notario o la Cámara de Comercio), se debe proceder a COMUNICAR la apertura del procedimiento a: a) Registro de bienes para su anotación preventiva de constancia en la hoja del bien; b) Registros públicos y Registro Civil que corresponda; c) Registro Público Concursal; d) AEAT y TGSS; e) Representantes de los trabajadores. Y llegado a la situación de concurso, se deberá presentar ante el Juzgado competente, al que se había notificado el inicio del procedimiento de mediación. 
La CONSECUENCIA INMEDIATA a tenor de lo recogido en el art. 235 LC: i) para el deudor, la obligación de no realizar actos de disposición o administración que excedan de los normales de su actividad; ii) para el acreedor, se prohíbe durante 3 meses ( 2 meses en el supuesto de persona física no empresario o profesional) la ejecución separada, judicial o extrajudicial, y se suspende por el mismo período la que se encuentre en marcha, salvo los créditos con garantía real de bienes no afectos a la actividad o necesarios para desarrollarla, así como la vivienda habitual (art. 235.2 LC). Para el resto de bienes, la suspensión es por el tiempo indicado previo a reanudarse. Se suspende el devengo de intereses (art. 59 LC). Se prohíben acciones individuales tendentes a romper la par conditio creditorum.

El PROCEDIMIENTO propiamente dicho se puede articular según los siguientes pasos:

1. Aceptado el cargo por el mediador, art. 234 LC, en el plazo de 10 días procederá a convocar a los acreedores indicados por el deudor a reunión en un plazo máximo de 2 meses en la localidad del domicilio del deudor, con indicación de día y hora, con la finalidad de alcanzar un acuerdo y determinándose la masa pasiva (volumen de deuda y titularidad) y garantías que consten, y notificando datos necesarios para que los acreedores pueda comunicar y corregir sus créditos, llegándose a la realidad pasiva del deudor. Para el supuesto de persona física no empresario o profesional, la reunión debe celebrarse en el plazo de 30 días desde la convocatoria.

2. Hasta 20 días anteriores a la reunión, previo acuerdo con el deudor, remitirá el mediador PROPUESTA de AEP, que podrá consistir en esperas de hasta 10 años, quitas que no sean del $100 \%$, cesión de bienes o derechos (si de su valoración no se intuye menoscabo para el conjunto de acreedores), la conversión en acciones o participaciones societarias de la deuda, o en préstamos participativos por un plazo no superior a 10 años, obligaciones convertibles o préstamos subordinados, o cualquier otro instrumento financiero diferente a la deuda original. Junto a dicha propuesta debe acompañarse un PLAN DE PAGOS, que contemple los recursos previstos detallados en un PLAN DE VIABILIDAD global. La propuesta no podrá consistir en la liquidación global del patrimonio.

3. Los acreedores gozan de 10 días para realizar PROPUESTAS ALTERNATIVAS o modificaciones, en cuyo caso el mediador deberá remitir nuevo plan de pagos y de viabilidad. 
4. Los acreedores, a tenor del arts. 237 y 238 LC, deberán acudir a la reunión convocada, salvo que hubiesen manifestado su APROBACIÓN U OPOSICIÓN en los 10 días anteriores (art. 237.1 LC), excepción de los que tengan constituida a su favor garantía real. Los efectos de no acudir o manifestarse es la calificación de los créditos como subordinados en el supuesto de que, fracasada la negociación, sea declarado el concurso consecutivo.

5. El art. 238 LC distingue distintas mayorías según el acuerdo propuesto: a) Un 60\% del pasivo correspondiente a acreedores cuyos créditos no estén sostenidos con garantía real o por la parte de dichos créditos que excedan el valor de la garantía (en concepto de principal, intereses u otras cantidades debidas), con un plazo no superior a 5 años y quitas no superiores al $25 \%$, o conversión de deuda en préstamos participativos en el mismo plazo; b) Un 75\% del pasivo en el mismo supuesto de créditos anterior, pero con esperas hasta 10 años y quitas superiores al 25\%, o conversión de deuda en préstamos participativos en el mismo plazo; c) Se extiende a los acreedores con garantía real que manifestaron su no adhesión al acuerdo, por la parte de sus créditos que no exceda del valor de al garantía, cuando concurra un $65 \%$ del pasivo sin dichas garantías, calculado en función de la proporción del valor de las garantías sobre el valor total de las garantías, siempre que las esperas sean por plazo no superior a 5 años y quitas no superiores al $25 \%$, o conversión de deuda en préstamos participativos; d) Afectará a los acreedores con garantía real, por la parte de sus créditos que no exceda de la garantía, cuando concurran el 75\% del pasivo calculado en función de la proporción del valor de las garantías sobre el valor total de las garantías, con esperas hasta 10 años y quitas superiores al 25\%. Alcanzada la mayoría, el mediador supervisará su cumplimiento. El art. 240 LC permite a los acreedores que no hayan suscrito el acuerdo o manifestado su no adhesión continuar su acción contra los obligados solidarios y garantes del deudor. Los que suscribieron el acuerdo mantendrán dichos derechos supeditados a la relación jurídica establecida. Los créditos afectados por el acuerdo quedan sometidos al plazo y forma de pago aprobado, siendo susceptible la dación en pago de deuda en los no afectados (art. 240.2 LC). Estamos ante una eficacia novatoria del acuerdo extrajudicial de pagos, que conlleva la extinción de la acción ejecutiva (art. 240.1 LC), lógica consecuencia de la fase del proceso que va de la aceptación de la insolvencia al propio concurso. 
6. El acuerdo debe elevarse a escritura pública, cerrando el Notario el expediente abierto, comunicándose al Juzgado. Si hubiera sido abierto por Cámara de Comercio, se presentará ante el Registrador Mercantil copia de la escritura para su cierre. En ambos casos se dará cuenta ante los registros públicos para cancelar las anotaciones por certificación o copia. El Registro Público Concursal publicará dicho acuerdo y los datos de identificación necesarios. Podrán oponerse, según art. 239 LC, los acreedores no convocados, los que no hubieran votado a favor o que hubieran manifestado su no adhesión, basándose en la falta de quórum (art. 236.1 LC) o en la desproporción de las condiciones aprobadas. La impugnación se sustanciará ante el Juzgado Mercantil competente por el trámite del incidente concursal (art. 194 LC), siendo su resolución susceptible de recurso de apelación. Los motivos tasados de oposición se centran en la falta de concurrencia de las mayorías exigidas, incumplimiento de los límites legales de quita y espera, indicando el art. 239.2 la desproporción como motivo, aunque su falta de concreción lo deja prácticamente en desuso. En este motivo la ley debería haber actuado como la reforma de la Ley concursal del 2011 en el tratamiento de la impugnación de la homologación de los acuerdos de refinanciación, en su D.A. 4. ${ }^{\mathrm{a} 24}$.

7. Si se incumple el acuerdo, o no se consigue aprobarlo, o bien se resuelve el incidente o recurso con su anulación, se debe entender que el deudor se encuentra en situación de insolvencia, y el mediador instará el CONCURSO CONSECUTIVO del art. 242 LC. En el supuesto de persona física no empresario o profesional el concurso se abre siempre en la fase de liquidación al no estar en juego la continuidad de la empresa. El art. 239.6 LC indica que «dará lugar» dando la apreciación de que la declaración tiene lugar de oficio. Nada más lejos de la realidad procesal, necesitando de impulso procesal. No obstante el calificativo "consecutivo" deriva de haberse intentado un acuerdo previo extrajudicial con los acreedores, sin acuerdo o que deviene incumplido. A nivel procedimental, el concurso consecutivo es un concurso que abre inmediatamente la fase de liquidación, excepcionándose el supuesto de insuficiencia de masa activa del art. 176 bis LC. El rigor para quién ha tratado de llegar a un acuerdo contrasta con el trato «más favora-

${ }^{24}$ SENÉS, Carmen, «La homologación de los acuerdos de refinanciación, ADCo, núm. 30 (septiembre-diciembre), 2013, págs. 68 y 69, comentado en Revista de derecho Civil, vol. I, núm. 1 Estudios, pág. 64. 
ble» dispensado por la LC al concursado directo, lo que de inicio podría desincentivar este camino ${ }^{25}$. A nivel subjetivo, «salvo justa causa» el mediador es designado (art. 242 LC) Administrador Concursal, sentido de continuidad a la función negociadora que la ley le da, porque su retribución es la que opera y se fija en el procedimiento extrajudicial ${ }^{26}$, lo que debería incentivar el tratar de conseguir un acuerdo, lo que en la práctica no se está materializando. A nivel sustantivo la principal novedad del RDL $1 / 2015$ es que los arts. 176 bis y 178 bis amplían notablemente el régimen de exoneración de deudas de la Ley 14/2013 de emprendedores, excepcionando ampliamente el principio de responsabilidad patrimonial universal del art. 1911 Código Civil. La Ley prevé un mecanismo de exoneración de deudas para el empresario persona física o para ésta no empresario siendo susceptible de declaración en dos supuestos: a) conclusión de las operaciones de liquidación o puesto de manifiesto que su patrimonio, masa activa, resulte insuficiente para pagar sus deudas; b) dentro del plazo de rendición de cuentas (art. 152.3 LC) o en trámite de audiencia por insuficiencia de la masa activa (art. 176 bis LC).

\section{BENEFICIO DE LA EXONERACIÓN DEL PASIVO INSATISFECHO ${ }^{27}$}

El art. 178 bis LC regula lo que denomina beneficio de la exoneración del pasivo insatisfecho (en adelante BEPI), introducido por el RDL 1/2015 y reformado por la Ley 5/2015 de 28 de julio. La solicitud la realiza el deudor, asistido de Letrado, pero no necesariamente de Procurador $^{28}$ ante el Juez del concurso, bien al concluir la liquidación de la masa activa, tras la audiencia a las partes del informe

${ }_{25}$ PULGAR EZQUERRA, Juana, «Implicaciones concursales de la Ley 14/2013 de apoyo a los emprendedores y su internacionalización», Especial emprendedores, las leyes que los apoyan, Ed. La ley, Madrid, 2013, aptdo. III-3

${ }^{26}$ La Exposición de Motivos de la Ley 14/2013 denomina «negociador» al mediador concursal.

27 Es bueno traer aquí a colación la distinción respecto de la «condonación de deudas» del Capítulo IV del CC, art. 1156 y 1187 . Ésta es un modo de extinción de las obligaciones, en la que el titular del derecho, el acreedor, renuncia a su derecho de crédito y la consecuente acción contra el deudor, poniendo fin a la relación obligatoria existente. Produce el mismo efecto pero en la exoneración es la insolvencia la causa autónoma de la extinción de la deuda. En este sentido se puede estudiar a FUENTESECA DEGENEFE, «La condonación de deudas». Edit. Edersa, Madrid, 2003.

${ }^{28}$ Aunque el art.184.2 exige que el deudor actúe siempre representado por Procurador de los Tribunales y asistido de Letrado, la D.A. 3. ${ }^{\text {a }}$ del RDL 1/2015 exime de 
final de las operaciones efectuadas, o, en los casos de concursos que concluyan por insuficiencia inicial o sobrevenida de la masa activa, cuando se de traslado a las partes del informe del administrador concursal justificativo de la liquidación de la masa activa o de la justificación de la petición de conclusión por insuficiencia sobrevenida. Y establece un único requisito a justificar centrado en la calificación del deudor como «deudor de buena fe», concepto jurídico indeterminado y que la ley establece sujeto a una apreciación de carácter procedimental con tintes penales. Esta elección del legislador suscita controversia. Se deriva tal condición (art. 178 bis 3, en línea con los términos de los arts. 27 a 29 del Código Penal) de que el concurso no haya sido declarado culpable, que el deudor no haya sido condenado en sentencia firme por delito contra el patrimonio, el orden socioeconómico, falsedad documental, contra la Hacienda Pública y la Seguridad Social o contra los derechos de los trabajadores en los 10 años anteriores a la declaración de concurso, que haya satisfecho en su integridad los créditos contra la masa y los créditos concursales privilegiados, y, para el supuesto de no haber intentado un acuerdo extrajudicial de pagos (art. 178 bis $3.4 .^{\circ}$ ), haber satisfecho el $25 \%$ de los créditos ordinarios concursales. Y aún para el supuesto de no poder satisfacer dichos créditos, abre la Ley motivo suficiente para conceder la BEPI si se somete a un plan de pagos, colaborando de conformidad con el art. $42 \mathrm{LC}$, siempre que no haya rechazado una oferta de empleo adecuada en los últimos 4 años, y no haber obtenido este mismo beneficio en los 10 años anteriores, con expresa anotación en le Registro Público Concursal ${ }^{29}$.

Procedimentalmente el beneficio es declarado por el Juez mediante Auto, concediéndose con carácter provisional en la resolución de la conclusión del concurso en fase de liquidación, previo informe presentado por el AC del art. 152.2 LC, y correspondiendo la carga de la prueba de concurrencia de los requisitos del art. 178 bis 3 al deudor, siendo susceptible de recurso por no darse los requisitos necesarios (art. 178 bis 3). Para el supuesto de oposición se resolverá mediante incidente concursal. Si se diera supuesto de apertura de la sección de calificación, el trámite de exoneración se suspende o no se inicia hasta que concluya la calificación por resolución firme.

Si se cumplen los requisitos del 178 bis $3.4 .^{\circ}$ la exoneración es definitiva y sobre la totalidad del pasivo concursal no satisfecho. Si

\footnotetext{
Procurador de los Tribunales cuando el deudor es persona natural (sin distinguir si es empresario o no).

${ }_{29}$ Conclusiones del Seminario de Jueces de lo Mercantil y Juzgado de Primera Instancia número 50 de Barcelona, de 15 de junio de 2016.
}

(C) UNED. Revista de Derecho UNED, núm. 23, 2018 
se cumplen los requisitos del 178 bis $3.5 .^{\circ}$, la exoneración es provisional y se extiende a los créditos ordinarios y subordinados, aún los no comunicados, y a la parte no cubierta por la garantía en los privilegiados (art. 178.5 LC). Quedan excluidos los créditos públicos, los privilegiados con garantía real (art. 90.1 LC) y los créditos por alimentos, y no se extiende a los deudores solidarios, avalistas o garantes del deudor, así como las deudas explícitamente no exoneradas, que estarán sujetas a un plan de pagos (art. 178 bis 6 LC). Si el concursado tuviera un régimen económico matrimonial de gananciales u otro de comunidad no liquidado, el BEPI se extenderá al cónyugue del concursado aún no encontrándose en concurso, respecto de las deudas anteriores a la declaración del concurso de las que debiera responder el patrimonio común ${ }^{30}$.

Dada la provisionalidad, es susceptible de revocación por los trámites del juicio verbal (art. 178 bis 7 LC) derivadas de una mejora económica o el incumplimiento del calendario de pagos de las deudas no exoneradas. Transcurridos cinco años sin que se haya revocado el plan de pagos, se concederá al deudor la remisión definitiva de las deudas, siendo impulsado a instancia de parte. Y aún no cumplido el plan de pagos, y no habiendo sido revocada la exoneración provisional, el deudor puede solicitar la conversión a definitiva si hubiera destinado al menos la mitad de los ingresos percibidos que no tuvieran la consideración de inembargables o la cuarta parte de dichos ingresos acumulado con la concurrencia de las circunstancias previstas en el art. 3.1 a) y b) del RDL 6/2012, de 9 de marzo, de medidas urgentes de protección de deudores hipotecarios sin recursos, respecto de la unidad familiar y circunstancias familiares de especial vulnerabilidad. La exoneración definitiva del art. 178 bis 8 alcanzará a la totalidad del pasivo insatisfecho, incluidos créditos contra la masa, créditos concursales por alimentos y créditos públicos. Para el supuesto de revocación, los acreedores recuperan la plenitud de sus acciones frente al deudor para hacer efectivos los créditos no satisfechos a la conclusión del concurso.

En definitiva, el AEP ha conllevado un cambio sustancial en el proceso concursal, en su instituto preconcursal. PULGAR ${ }^{31}$ asevera que se ha producido «un tránsito de un sistema basado en la autonomía de la voluntad de las partes ex artículo 1.255 del Código Civil, que debe regir en todo caso el marco extrajudicial de composición de las

${ }^{30}$ Cit. Conclusiones del Seminario...

31 PULGAR EZQUERRA, Juana, «Implicaciones concursales de la Ley 14/2013 de apoyo a los emprendedores y su internacionalización», Especial emprendedores, las leyes que los apoyan, Ed. La ley, Madrid 2013, aptdo. III-3 (www.laley.es) 
crisis económicas, a una procedimentalización de dicha extrajudicialidad», todo y que la Exposición de Motivos de la Ley 14/2013 la define como un mecanismo de negociación extrajudicial.

\section{RESULTA MEJORABLE Y CONVIENE MEJORARLA}

Analizar qué debemos mejorar y el por qué nos ayuda siempre a comprender la realidad. El primer punto que debemos cuestionarnos es si el principio de responsabilidad patrimonial universal $^{32}$ del art. 1911 del Código Civil debe derogarse. Nos encontramos ante un ordenamiento jurídico cuya responsabilidad se caracteriza por la patrimonialidad y la universalidad ${ }^{33}$. La correspondencia entre solvencia y responsabilidad refuerza nuestro ordenamiento. La refundación o replanteamiento de este principio parece en ocasiones puesto en duda por determinadas y aisladas resoluciones judiciales pero centra nuestro Derecho ${ }^{34}$. $\mathrm{Y}$ es por lo que no veo razones para ello, dado que estamos ante un principio central de nuestro Derecho positivo: las deudas se han de pagar, porque el sistema debe tener unos fundamentos sólidos. Excepcionarlo sólo mejora el sistema al que protege, reforzando la credibilidad del propio sistema jurídico. A modo de ejemplo, una excepción al principio de responsabilidad patrimonial universal es la regulada en el artículo 140 de la Ley Hipotecaria que prevé la posibilidad de limitar la responsabilidad del deudor al bien hipotecado y siempre que así se haya pac-

32 En este sentido, LASARTE, Carlos. «Derecho de Obligaciones. Principios de Derecho Civil II», 17. ${ }^{a}$ ed., Marcial Pons, Madrid, 2013, para quién constituye «una consecuencia natural de la obligación que ha de ser cumplida».

${ }^{33}$ CAPILLA RONCERO, Francisco. «La responsabilidad patrimonial universal y el fortalecimiento de la protección del crédito, Fundación universitaria de Jerez, Cádiz, 1988., pág. 9, la responsabilidad que emana del artículo 1911 Cc no sólo será patrimonial y universal, tal y como se desprende de dicho artículo, sino que además, se tratará de una responsabilidad general y reparadora del daño causado. LASARTE, Carlos. «Derecho de Obligaciones. Principios de Derecho Civil II, 17. a ed., Marcial Pons, Madrid 2013, págs. 208-210 sistematiza la sustancia de la responsabilidad patrimonial universal en los siguientes aspectos: (i) responsabilidad general, (ii) derivada del incumplimiento, (iii) personal, como concepto este contrapuesto a responsabilidad de bienes, (iv) exclusivamente patrimonial y (v) universal. ROCA SASTRE, Ramón M. ${ }^{a}$ y PUIG BRUTAU, José. «Estudios de Derecho privado», Volumen I, Aranzadi, Madrid, 2009, pág. 225 advierten de la diferencia entre la responsabilidad universal y la responsabilidad ilimitada. En el artículo 1911 Cc tiene cabida la responsabilidad universal, pero no ilimitada. Se deberá tener en cuenta que el deudor responderá con todos sus bienes, pero sólo en la cuantía o con los bienes suficientes para cubrir la responsabilidad.

${ }^{34}$ Auto de la sección 2.a de la Audiencia Provincial de Navarra (número 111/2010) de 17 de diciembre de 2010.

(c) UNED. Revista de Derecho UNED, núm. 23, 2018 
tado expresa e inequívocamente en el propio negocio jurídico por voluntad de ambas partes, o la herencia a beneficio de inventario del art. $1.023 \mathrm{CC}$.

Cuestionable resulta también el que para tener acceso a la exoneración de determinados créditos, deba hacerse frente a créditos con privilegio no exonerables, con especial incidencia en deudas con AEAT y TGSS. El mantenimiento de dichas exoneraciones contradice las propias recomendaciones del $\mathrm{FMI}^{35}$ al respecto, dado que el Estado, como acreedor, en este campo no pude tener una posición privilegiada que socava la finalidad y filosofía del sistema creado. $\mathrm{Y}$ en el mismo sentido los informes del Banco Mundial ${ }^{36}$. Esto, además, se realiza con carácter general, no adaptado a cada caso, como ya se da en otros países europeos. Nuestra LC remite a la normativa específica de estos organismos para la negociación, aplazamiento y pago de dichas deudas de personas físicas, empresarios o no, haciéndose necesaria la adecuación en materia tributaria y de Seguridad Social. No es tanto el proteger a un acreedor frente a otro como el determinar qué deudas merecen la consideración de exonerables; he de insistir en la adaptación al caso. Una deuda por alimentos, por sus carácter asistencial, no deberían exonerarse. Y, pro seguir con los ejemplos, es común que se excluyan la acciones indemnizatorias y las sanciones. En nuestra legislación una indemnización de daños y perjuicios a una persona especialmente relacionada con el deudor, tiene el carácter de crédito subordinado (art. 93 LC) y, por tanto, será exonerable ${ }^{37}$.

Se debe dar un paso más al tratar al deudor que no tiene activos, simplificando el procedimiento, dado que, si bien no sería necesario acudir con abogado, éste se hace indispensable para personas que lo más normal es su desconocimiento al respecto buscando un asesoramiento, con un coste que no resulta, por ser accesorio, susceptible del beneficio de justicia gratuita, cuando hablamos de una persona «insolvente». La novedad debería pasar por un proceso directo de concurso y una provisionalidad más corta. Cinco años se convierte en una pesada carga de duda. La Recomendación de la Comisión Europea de 12 de marzo de $2014^{38}$ sobre un nuevo enfoque frente a

35 http://ep00.epimg.net/descargables/2014/07/10/2509f16067f17898af32a 70b8958b979.pdf

$36 \mathrm{http}: / /$ siteresources.worldbank.org/INTGILD/Resources/WBInsolvencyOf NaturalPersonsReport_01_11_13.pdf

37 CUENA CASAS, Matilde, «A propósito del Real Decreto Ley 1/2015, de 27 de febrero, de mecanismo de segunda oportunidad, reducción de carga financiera y otras medidas de orden social», ElNotario.es, 30 de marzo de 2015 (revista digital).

38 Ver nota 13. 
la insolvencia y el fracaso empresarial, recordemos referida a empresarios pero con la recomendación de su extensión a consumidores, expresa que "a los empresarios (y también a los consumidores) se les deberían condonar totalmente las deudas incursas en las insolvencia en un plazo máximo de tres años». Aquí son cinco años parece que se quiso equiparar con el entonces nuevo plazo de prescripción de las acciones personales, hoy en vigor lo cual me parece absurdo porque, como indica CUENA CASAS ${ }^{39}$ "no sé qué tiene que ver la duración de un plazo de prescripción para ejercitar acciones personales (que es susceptible de interrupción) con lo la fijación de un plazo para el cumplimiento de un plan de pagos. Cuanto más tarde el deudor el liberarse del pasivo pendiente, más se ralentizarán los beneficios de la medida».

Se debería dar margen a la apreciación de la «buena fe». Con el sistema actual el Juez no tiene margen de interpretación y valoración de las causas de sobreendeudamiento y sólo la apreciación desde el punto de vista penal tasado mide dicha calificación. El juez debería tener margen para valorar la conducta del deudor, observancia de su honestidad revestida de mala suerte, y poder valorar (Código de Comercio del sistema francés ${ }^{40}$ ) la actitud responsable del acreedor ${ }^{41}$ en la concesión del crédito. Aquí cabría la opción de dación en pago del deudor más vulnerable con tiempo de permanencia en la que constituye su vivienda habitual sometida a un alquiler adecuado a la realidad económica familiar pero limitada en el tiempo. Y debería poder optar en cuanto a los créditos actualmente no exonerables en supuestos de personas con dependencia, facilitando la posibilidad de incumplir el plan de pagos de éstas deudas. Debe poder arbitrarse un sistema de control del «moroso profesional» permitiendo al Juez mayor margen respecto a la exoneración de los cré-

${ }^{39}$ CUENA CASAS, Matilde, «A propósito del Real Decreto Ley 1/2015, de 27 de febrero, de mecanismo de segunda oportunidad, reducción de carga financiera y otras medidas de orden social», ElNotario.es, 30 de marzo de 2015 (revista digital)

${ }^{40}$ En el sistema francés la «buena fe» también se conceptualiza fuera de la ley. Así es de llamada recurrente la Sentencia de la Cour d'Apelation d'Angers, de 23 de mayo de 2006, Juris-Data num 2006-324205, CCC2007, comentario 112, en la que se examina en profundidad este extremo.

${ }^{41}$ Con la intención de solucionar el grave problema del sobreendeudamiento se aprobó la Ley 2005-845, de 26 de julio de 2005, sobre la responsabilidad por concesión abusiva de crédito, lo que supuso en el país galo una nueva redacción del artículo L.650-1 del Código de Comercio, con la siguiente redacción: «Los acreedores no responderán de los perjuicios generados a consecuencia de las ayudas prestadas, salvo en los casos de fraude, de injerencia evidente en la gestión del deudor o e obtención de garantías desproporcionadas como contrapartida de dichas ayudas. Cuando se establezca la responsabilidad de un acreedor, las garantías recibidas como contrapartida de su ayuda serán nulas». 
ditos pero también un mayor rigor en la apreciación de la conducta del deudor ${ }^{42}$.

El Juez determinado por la Ley en concursos de persona física debería ser el especialista (evitando el actual traslado de competencias $^{43}$ ), el del Mercantil, liberando los ya de por sí cargados juzgados de 1. ${ }^{a}$ instancia, devolviendo al lugar del que no debieron salir competencialmente, el lugar donde se vive la problemática y se entiende por análisis al momento. La Exposición de Motivos de la Ley Orgánica 7/2015 justificaba esta modificación competencial indicando que «se incluye también un conjunto de medidas para lograr una mayor agilización y especialización en las respuestas judiciales, cuyo objetivo es doble: de un lado, acabar con los problemas de retraso que existen en algunos órganos jurisdiccionales y, de otro lado, incrementar la calidad de la respuesta ofrecida al ciudadano». Y para ello articula «un mejor reparto de asuntos entre Juzgados», sin tener presente el origen y motivo de la creación de los Juzgado de lo Mercantil, sobre todo desde el punto de vista de competencias. De hecho, la Exposición de Motivos de la Ley Orgánica 8/2003, de 9 de julio, para la Reforma Concursal, por la que se modifica la Ley Orgánica 6/1985, de 1 de julio, del Poder Judicial lo justificaba por la conveniencia de obtener «resoluciones de calidad en un ámbito de indudable complejidad técnica», que las cuestiones fuesen resueltas por «titulares con conocimiento específico y profundo" y que las resoluciones fuesen dictadas con «mayor celeridad, pues ese mejor conocimiento del juez en la materia se traducirá en una mayor agilidad en el estudio y resolución de los litigios». De aquí que crea que atribuir a los Juzgados de Primera Instancia el conocimiento de los concursos de personas físicas no empresarios no puede tener justificación en el criterio de es-

42 El sistema alemán se basa en «la segunda oportunidad ganada», debiendo tratar de pagar, conforme a un plan de pagos las deudas, demostrando una conducta de «buen y desafortunado pagador» previo. Ver ZABALETA DÍAZ, «La condonación de las deudas pendientes en el Derecho Concursal Alemán», AA.VV., Estudios sobre la Ley Concursal. Libro Homenaje a Manuel Olivencia, Tomo I, Madrid 2005, pág. 893.

${ }^{43}$ Con la modificación del artículo 85.6 en la Ley Orgánica del Poder Judicial («LOPJ») y la modificación del artículo 86 ter.1 LOPJ y del artículo 45 de la Ley de Enjuiciamiento Civil («LEC»), se articuló un traslado de competencias correspondiendo a los Juzgados de Primera Instancia el conocimiento «de los concursos de persona natural que no sea empresario en los términos previstos en su Ley reguladora». Esta previsión se completa con la reforma del artículo 86 ter.1 LOPJ, según el cual «los Juzgados de lo Mercantil conocerán de cuantas cuestiones se susciten en materia concursal, en los términos previstos en su Ley reguladora y sin perjuicio de lo dispuesto en el artículo 85.6». En similares términos se expresa el artículo 45.2 b) LEC, al señalar que los Juzgados de Primera Instancia conocerán «de los concursos de persona natural que no sea empresario». 
pecialización. Por ello creo que no resulta adecuado el argumento de alivio de la carga de trabajo de los Juzgados de lo Mercantil, argumento compartido con la decisión de liberar a esos Juzgados de las acciones individuales establecidas en la legislación sobre condiciones generales de la contratación y protección de consumidores y usuarios, aunque aquí menos cuestionable.

Se debe agilizar el proceso, acortando plazos, y evitar la desafección de determinadas figuras que pueden entorpecer y ralentizar el proceso (Notario que no acepta, cuando es el único de la plaza, o mediador que no ve rentable aceptar el supuesto) y con ello agravan la situación del deudor, quién sólo temporalmente, en la fase de acuerdo extrajudicial, ve paralizada la ejecución de su vivienda (límite en tres o dos meses). Precisamente en esta fase de ejecución de la vivienda, debería volverse a tasar pero mantenerse el límite de la tasación inicial para ajustar que la garantía que para el acreedor resultó suficiente y necesaria, mantenga dicho valor ante circunstancia de sobreendeudamiento sobrevenida culposa o no, pero no dolosa.

Por la problemática social que se ha dado, se debe acoger la relación de parentesco del fiador por consanguinidad o afinidad con la del deudor hasta el tercer grado para darle alcance a la exoneración del pasivo insatisfecho. Padres, abuelo o tíos, fiadores de hijos e inclusive hipotecantes en garantía de operaciones de terceros, también merecen que el alcance de la segunda oportunidad sea compartida. Ello también incidiría en que las entidades acreedoras impulsaran planes de pagos y reestructuraciones de deudas ${ }^{44}$. Aún con la ley actual, se han dado sentencias que ya cuestionan la LC como el Juzgado Mercantil 3 (Autos de fecha 17 y 18/05/2016) y el Juzgado de Primera Instancia 50 (Auto 17/01/17 entre otros) han dictado resoluciones en las que, al conceder el BEPI definitivo al deudor, extiende la exoneración a los fiadores al entender que su obligación ha quedado extinguida con la principal. Cuestionan el error de la ley al excluirlos, dado que debemos considerar que la Ley no ha modificado el artículo 1847 del Código Civil, que regula el régimen de la fianza, junto con los artículos 1143 y 1146 en relación con los artículos 1190 y 1207 del Código Civil. La fianza requiere siempre de una

44 El 178 bis.5.2. ${ }^{\circ}$ Lc, señala al hablar de los fiadores, ...: «...ni subrogarse por el pago posterior a la liquidación en los derechos que el acreedor tuvieses contra aquél, salvo que se revocase la exoneración concedida.»

Es decir, el deudor solidario, el fiador o el avalista no podrán repetir el pago al deudor principal exonerado de pago por la Ley de segunda oportunidad, salvo que este beneficio fuese revocado. 
obligación principal válida, que es la que garantiza, siendo su principal característica la accesoriedad. No puede su subsistir la fianza sin deuda, y dicho concepto no ha sido modificado por el legislador, por lo que en sede concursal es difícil reconocer con la subsistencia que aquí discutimos dicha figura jurídica, la fianza, como tal; la jurisprudencia constitucional avala el que que los derechos y obligaciones sean reconocibles como tales.

El 2 de febrero de 2018 ha tenido entrada la Proposición de Ley 122/000165 presentada por el grupo Ciudadanos que no ha sido la única desde su vigencia y debemos entender que habrá más. En este concreto caso se recogen algunos de los puntos aquí tratados pero aún no ha sido tomada en consideración.

V. ¿OTRAS PROPUESTAS (SOLUCIONES) SON POSIBLES?:

MEDIDAS JUDICIALES Y EXTRAJUDICIALES EN CATALUNYA

PARA SOLVENTAR EL SOBREENDEUDAMIENTO DEL

CONSUMIDOR RELACIONADO CON LA VIVIENDA

HABITUAL, CON ESPECIAL MENCIÓN DE LA LEY 24/2015, DE 29 DE JULIO, DE MEDIDAS URGENTES PARA AFRONTAR LA EMERGENCIA EN EL ÁMBITO DE LA VIVIENDA Y LA POBREZA ENERGÉTICA, Y LA LEY 4/2016, DE 23 DE DICIEMBRE, DE MEDIDAS DE PROTECCIÓN DEL DERECHO A LA VIVIENDA DE LAS PERSONAS EN RIESGO DE EXCLUSIÓN RESIDENCIAL, AMBAS SUSPENDIDAS SU VIGENCIA Y APLICACIÓN EN DETERMINADOS PRECEPTOS (LOS SUSTANTIVOS) PERO QUE ABREN CAMINO

V.1. Ley de Catalunya 24/2015, de 29 de julio, de medidas urgentes para afrontar la emergencia en el ámbito de la vivienda y la pobreza energética, publicada en DOGC el 5 de agosto de 2015, que viene a establecer una serie de medidas contra el sobreendeudamiento de los consumidores, personas físicas, relacionados con la vivienda habitual y otras medidas dirigidas a evitar la pobreza energética, y que entró en vigor al día siguiente de su publicación. No trato de realizar juicios políticos, dado que fue recurrida ante el Tribunal Constitucional $^{45}$, sino analizar lo que 9 artículos, 1 DA, 3 DT y 7 DF

${ }^{45}$ El Institut d'Estudis Autonòmics de Catalunya (Análisis de la legislación de Catalunya aprobada durante el segundo cuatrimestre de 2015, de 26 de enero de 2016) remarcó al respecto que «en relación con la mayoría de preceptos de esta ley, se han producido discrepancias competenciales con el Estado5, discrepancias que pueden tener su origen, fundamentalmente, en una diferente interpretación del alcance de las competencias autonómicas en materia de Derecho procesal y de energía». 
pueden aportar al consumidor que no ve salida a su inafrontable endeudamiento, con especial sentido en la hipoteca y el alquiler, así como las dificultades para hacer frente a los suministros básicos.

Hemos analizado lo que la Ley 25/2015, de 28 de julio, de mecanismo de segunda oportunidad, reducción de la carga financiera y otras medidas de orden social, que venía a completar el RDL 1/2015, de 27 de febrero, marca la posibilidad de que el deudor (de buena fe) pueda quedar exonerado del pasivo insatisfecho, previo paso por la liquidación de su patrimonio (recordemos la anotación que hacía del magistrado Fernández Seijo quién indicaba que no estamos ante un "premio»). Pero esta Ley trataba de ir más allá. Cabe mencionar que tanto el artículo 47 de la Constitución Española como el artículo 26 del Estatut d'Autonomia de Catalunnya, reconocen a todas las personas el derecho a disfrutar de una vivienda digna y adecuada, siendo deber de los poderes públicos promover y establecer las medidas pertinentes para hacer efectivo este derecho. Además, el artículo 112-1 de la Ley 22/2010, de 20 de julio, del Código de Consumo de Catalunya establece que los derechos de los consumidores tienen consideración de derecho básico, siendo objeto de especial protección. La mencionada Ley se debería aplicar a todas las personas consumidoras en el ámbito territorial de Catalunya. Y en la Ley que analizamos el artículo 1 circunscribe la aplicación a las personas físicas residentes en Catalunya (no identifica la vivienda habitual como matriculada en Catalunya), que se encuentren en riesgo o puedan encontrarse de insolvencia derivada del pago de la vivienda habitual. Para ello venía a articular un proceso de MEDIACIÓN ${ }^{46}$ tutelado por las denominadas Comisiones de Sobreendeudamiento ${ }^{47}$, y con acceso a un posterior procedimiento judicial simplificado. Si hablamos de mecanismo de mediación, técnicamente se da entrada a que el propio acreedor pueda solicitar dicho procedimiento (art. 2), lo cual reforma el artículo 132.4 del propio Código de Consumo de Catalunya por esta extensión al acreedor de la potestad para iniciar el proceso, y ello elimina la excepción que operaba a la paralización de los procedimientos de ejecución hipotecarios en Catalunya cuando el acreedor no consumidor no había tratado previamente de acudir a la institución de la mediación (art. 132.4) alegándose que el Decreto de Catalunya 98/2014, de 8 de julio sobre procedimiento de mediación en materia de consumo, el único legitimado para iniciar

${ }^{46}$ De conformidad con la Ley 22/2010, de 22 de julio, del Código de consumo de Catalunya.

47 Ver notas 7 y 9 y comentarios en texto al respecto de la creación de organismos similares.

(C) UNED. Revista de Derecho UNED, núm. 23, 2018 
el proceso de mediación era el consumidor. Dicha mediación está tutelada por un organismo de nueva creación, la Comisión de Sobreendeudamiento, de ámbito administrativo que tratará de regular un acuerdo de plan de pagos o reestructuración de deuda, revisable por el Juez, aunque, quizás fruto de la novedad, no señala las competencias de jurisdicción (contencioso-administrativo, civil...) ni el proceso a realizar (recurso, alegaciones...). Mi parecer es que los derechos que se defienden son más del ámbito civil que del administrativo, y por ende, fijándonos en la Ley de arbitraje (donde el Juez de primera instancia resuelve en ayuda), como proceso extrajudicial, la competencia objetiva debería recabar en el ámbito civil, y a mayor incidencia la modificación de la LOPJ 6/1985, de 1 de julio, que extrae del ámbito del Juez Mercantil el conocer de los concursos de personas físicas.

Para el supuesto de que la mediación falle indica el artículo 3.1 que el consumidor afectado "puede solicitar la apertura del correspondiente procedimiento judicial simplificado, con el objetivo de buscar las fórmulas apropiadas para la satisfacción de las deudas derivadas de una relación de consumo, incluidas las que se derivan de la vivienda habitual». Y es el análisis de qué debemos entender por "procedimiento judicial simplificado» donde radica la ausencia técnica de la Ley (al menos genera importantes dudas de aplicación, debiendo acudir al auxilio interpretativo de otras leyes), aunque el motivo de la inaplicación haya sido de diferente raíz. Lo que marca el propio art. 3 es que el Juez debe resolver y establecer un plan de pagos tras analizar las circunstancias del sobreendeudamiento y las razones de falta de acuerdo, así como se hace recaer (art. 3.3) en el acreedor el impulso de la liquidación de activos para el supuesto de incumplimiento del plan de pagos, excluyéndose los bienes inembargables, y, a la vista de las circunstancias personales del consumidor, puede acordar la cancelación de los importes no satisfechos ${ }^{48}$. Nuevamente abrimos la ley a un concepto abstracto no delimitado cual es la delimitación de las "circunstancias personales del consumidor», que sin duda abre campo al desarrollo de criterios de valoración a consensuar. Y novedoso, y sin duda aspecto que en Catalunya hubiera decantado por este proceso frente al concursal a muchos consumidores, es el art. 3.4 que extiende los efectos de dicha cancelación del pasivo insatisfecho al fiador «que tenga con el deudor una relación de parentesco por consanguinidad o afinidad de hasta el tercer grado». Por tratarse de una resolución que pone fin al proceso, con-

48 No es la BEPI del art. 178 bis de la LC, de indudable mayor carácter técnico, por el informe que debe acompañarse justificativo de la situación del concursado. 
forme al art. 206.1.3. ${ }^{\circ}$ de la LEC, debería adoptar forma de Senten$\mathrm{cia}^{49}$, procediendo interponer Recuso de Apelación.

Pero esta Ley no sólo se centra en el deudor hipotecario. Su artículo 5 trata las medidas para evitar los desahucios y se recogen todas aquellas medidas tendentes a evitar los desahucios que puedan producir una situación de falta de vivienda a aquellas personas que no dispongan de una vivienda alternativa y se encuentren dentro de los parámetros de riesgo de exclusión residencial definidos en la Ley, teniendo en cuenta que el desahucio puede derivar tanto de una ejecución hipotecaria como de un impago de alquiler. Para ello se establecen parámetros de medida del riesgo de exclusión por unidad familiar, centrado en el nivel de ingresos y el informe de servicios sociales valorativo. Y llegados al punto de inicio del procedimiento, tanto en su afección de dación en pago, desahucio por ejecución hipotecaria, compraventa, establece medidas protectoras del deudor tendente a facilitar propuestas de «alquiler social» (art. 5.7 da las características a cumplir para poder ser considerada como tal), y se debe crear un registro de demandantes de viviendas. Se traspasa la responsabilidad tanto a las personas jurídicas que puedan beneficiarse de las situaciones de precariedad, como a los Ayuntamientos como ente público garante del derecho a un vivienda digna. Y es que la Ley incide en los que denomina "grandes tenedores de vivienda" que son quienes más pueden hacer por el establecimiento de protocolos que hagan de estas realidades la búsqueda de una segunda oportunidad.

El art. 6 trata las medidas destinadas a paliar la pobreza energética, estableciendo obligación para la administración y los operadores energéticos de establecer protocolos para facilitar el acceso a las energías necesarias en el hogar.

Aún novedosa, pero a desarrollar y completar, el Pleno del Tribunal Constitucional, por providencia de 24 de mayo actual, admitió a trámite el recurso de inconstitucionalidad núm. 2501-2016, promovido por el Presidente del Gobierno, contra los artículos 2 (apartado 2), 3, 4, 5 (apartados 1, 2, 3, 4 y 9), 7, la disposición adicional, la disposición transitoria segunda (apartado primero y apartado segundo en lo que se refiere a la aplicación del artículo 7) y la disposición final tercera de la Ley del Parlamento de Cataluña 24/2015, de 29 de julio, de medidas urgentes para afrontar la emergencia en el ámbito de la vivienda y la pobreza energética, suspendiéndose, de

49 En el Acuerdo Extrajudicial de Pagos de la LC, el plan de pagos propuesto tras obtenerse el BEPI con carácter provisional, adopta la forma de Auto.

(C) UNED. Revista de Derecho UNED, núm. 23, 2018 
conformidad con el artículo 161.2 de la Constitución, la vigencia y aplicación de los preceptos impugnados desde la fecha de interposición del recurso, 5 de mayo de 2016, para las partes del proceso, y desde la publicación del correspondiente edicto en el BOE para los terceros. El recurso presentado se basa en la invasión de competencias estatales.

La respuesta del Govern de Catalunya, la Llei 4/2016, de 23 de diciembre, de medidas de protección del derecho a la vivienda de las personas en riesgo de exclusión residencial.

V.2. Llei 4/2016, de 23 de diciembre, de medidas de protección del derecho a la vivienda de las personas en riesgo de exclusión residencial

Con esta Ley el Govern trató de rellenar los espacios vacíos que dejó la suspensión del TC, e introduce cambios técnicos y de contenido en relación con la mediación en caso de sobreendeudamiento, la expropiación temporal del uso de viviendas vacías y ocupadas sin título habilitante en municipios de demanda acreditada cuando se cumplan los requisitos marcados por la Ley y la obligación de realojo. Se observa un interés por dar un sentido más técnico a la Ley, no olvidando las críticas recibidas por la 24/2015 con anterioridad a ser suspendida.

En su Preámbulo indica que «es una exigencia social que los poderes públicos reaccionen y aseguren el derecho a la vivienda de las personas afectadas por desahucios proveniente de ejecuciones hipotecarias, a fin de que puedan seguir ocupando su vivienda, lo cual debe suponer, en el marco de la normativa legal aplicable, la atribución a los poderes públicos del ejercicio de formas de actuación en el marco del ejercicio de sus competencias en materia de vivienda, consumo y servicios sociales.». Y afronta el redactado de esta ley como un mecanismo alternativo de respuesta y ayuda a las personas más desfavorecidas ante la suspensión de la Ley 24/2015 por parte del TC.

El objetivo es «la protección de las personas y unidades familiares en exclusión residencial como consecuencia de una situación de sobreendeudamiento, o que estén en riesgo de encontrarse en dicha situación».

Ya desde el título preliminar el redactor es consciente del «choque de trenes» jurídico declarando en su art. 1.2 que «en el caso de concurrencia de regímenes que resulten incompatibles, se aplica el que sea más beneficioso para la persona interesada, a petición de esta». El art. 3 indica las «Fórmulas de actuación» que desarrollará a lo largo 
de la Ley, herederas en gran parte de la suspendida Llei 24/2015, destacando:

— La mediación en el ámbito del consumo.

— La expropiación temporal de viviendas vacías (art. 15).

- La obligación de realojo de personas en riesgo de exclusión residencial (art. 16).

- La expropiación del derecho de uso para supuestos tasados (art. 17).

- La dotación de ayudas económicas que permitan mantener el uso de la vivienda habitual, el realojo y la tenencia de vivienda como apoyo básico.

- La colaboración poniendo medios y aportando información a la Administración de Justicia y los particulares implicados en procedimientos que pueden acarrear la pérdida de su vivienda.

El art. 4 realiza definiciones de algunos aspectos, destacando la definición de «sobreendeudamiento» asociada a causas sobrevenidas (por ende de «buena fe»), y sólo asimilable a la persona física, bien como titular, fiador deudor solidario y por relaciones de consumo ${ }^{50}$, la de «vivienda habitual» asociada a los condicionantes de permanente y continuado, "riesgo de exclusión residencial», según la definición del art. 5.11 y 12 de la Llei 24/2015, situación de «exclusión residencial» por ausencia de vivienda para la unidad familiar. Pero destaca la definición y reconocimiento de la «situación de ocupación sin título habilitante», definida como "en la que se encuentran las personas o unidades familiares en riesgo de exclusión residencial....y que ocupan de forma continuada y sin título, una vivienda que constituye su vivienda habitual».

El Título I traza el instituto de la creación de la "Comisión de Vivienda y Asistencia para situaciones de Emergencia Social», que amplía las funciones de las «comisiones de sobreendeudamiento» de la Llei 24/2015, y las regula en respuesta a la deficiente regulación anterior.

El Título II (arts. 10 a 14) se dedica a las medidas protectoras en situaciones de sobreendeudamiento centradas en la figura de la Mediación en el ámbito del consumo, con expresa referencia al Código

${ }^{50}$ La relación definida por el artículo 11-2 m del Código de consumo de Catalunya, aprobado pro Ley 22/2010, de 20 de julio.

(C) UNED. Revista de Derecho UNED, núm. 23, 2018 
de Consumo de Catalunya, extendido según los nuevos preceptos de la ley, y que, siguiendo lo indicado en la Llei 24/2015, busca un plan de saneamiento con una duración máxima de tres años, prorrogable hasta los cinco años, contemplando la reordenación de deudas, condonación parcial o total, liquidación del patrimonio del deudor o el acuerdo de liberación de deudas. Dicho plan es trasladado a la Comisión de Vivienda y Asistencia para situaciones de emergencia social que debe ratificar o resolver. Se da expresa naturaleza administrativa a la resolución siendo susceptible de recurso en el orden jurisdiccional contencioso-administrativo, no conculcándose la posibilidad de recurso de reposición ante el mismo órgano.

El Capítulo II se centra en la «Medidas para aumentar el parque social de viviendas asequibles en alquiler» (art. 15 a 18), contemplándose desde la expropiación temporal de viviendas (art. 15) por un período de cuatro a diez años, siempre bajo los principios que inspiran la ley, y con la pretendida cobertura del art. 72 de la Ley de Expropiación Forzosa de 16 de diciembre de 1954, correspondiendo soportar dicha acción a los grandes tenedores de vivienda (se debe generar un registro de viviendas vacías y ocupadas sin título habilitante), quienes recibirán un importe atendiendo a los criterios de alquiler social establecidos en al Llei 24/2015, o acudiendo, caso de no existir acuerdo, al Jurado de Expropiación de Catalunya para el establecimiento de un justi-precio. Cabe el realojo de los ocupantes de determinadas viviendas en riesgo de exclusión residencial (art. 16), centradas en la pérdida de la propiedad por motivos legales (dación en pago, venta por imposibilidad sobrevenida, ejecución hipotecaria o desahucio por impago de rentas). Es una obligación para el adquirente de dichas viviendas en determinados supuestos objetivos y subjetivos, sin olvidar que las personas afectadas estarán sujetas a tratar de cumplir un plan de acompañamiento económico, social y laboral, que las reintegre al ciclo económico. Y finalmente, cabe la expropiación del uso (art. 17) por un período de hasta tres años.

Las Disposiciones que acompañan el cuerpo de la Ley delimitan aspectos de desarrollo para dar sentido a la propia ley, como el fomento de la mediación, o los convenios entre administraciones, sin dejar de percibir que el núcleo de Barcelona necesita de un régimen especial por volumen en todos los aspectos, o la colaboración con otros operadores sociales (colegios profesionales, agencias de consumo...), o la remisión a la reglamentación posterior de los criterios de regulación de los arrendamientos urbanos, con expresa mención de la determinación de los supuestos de alquiler abusivo. 
Capítulo especial merece la DF $4 .^{\text {a }}$ relativa a la «ocupación de viviendas sin título habilitante», en respuesta a la situación en que la vivienda propiedad de la propia administración sea "ocupada», debiendo ser objeto de desarrollo reglamentario.

El Pleno del Tribunal Constitucional, admitió a trámite el recurso de inconstitucionalidad núm. 4752-2017, promovido por el Presidente del Gobierno, contra los artículos 8, apartado e), 10.1, $14.8,15,16,17$, disposición final tercera, apartado 3, y disposición final sexta de la Ley de la Comunidad Autónoma de Cataluña 4/2016, de 23 de diciembre, de medidas de protección del derecho a la vivienda de las personas en riesgo de exclusión residencial. Invocándose, como ha resultado habitual, el artículo 161.2 de la Constitución, produce la suspensión de la vigencia y aplicación de los preceptos impugnados desde la fecha de interposición del recurso, 29 de septiembre de 2017, para las partes del proceso, y desde la publicación del correspondiente edicto en el BOE para los terceros.

Es dejar sin sustancia la Ley.

\section{CONCLUSIONES}

Hemos avanzado pero la reinterpretación, basada en el resultado, dará pie a nuevos avances. Al analizar la Ley 25/2015, de 28 de julio, de mecanismos de segunda oportunidad, reducción de la carga financiera y otras medidas de orden social se han expuesto diferentes modificaciones (apartado 4) en las que se debería avanzar para, sin perder rigor y dar cobertura al objetivo de la misma, hacer del sistema de "segunda oportunidad» un procedimiento que sea consensuado como tal. Pero el debate se centra en si existen otras formas de dar esta segunda oportunidad fuera de una ley eminentemente mercantil, a menudo tildada de poco social, que abra otros caminos paralelos y no excluyentes. De aquí que, pese a la suspensión vigente, por el atrevimiento haya expuesto dos leyes del Parlament de Catalunya que abren otras expectativas en referencia a dotar a esos procesos, en la especial circunstancia del consumidor, de un cariz más social, y más acorde con otras legislaciones europeas con más solera.

En primer lugar es valorable el apostar por medios de solución de conflictos fuera del ámbito judicial, en este caso la MEDIACIÓN fuera de un contexto legal-mercantl (y por qué no el arbitraje, como recoge el propio Código de Consumo de Catalunya. Art. 112.4), apostando como en el resto de legislaciones europeas, por la creación de 
órganos ad hoc, la "comisión de...», centrada en el territorio y con la finalidad de conseguir un acuerdo no forzado. El deudor debe saber que de una composición amistosa se pasa a una judicial, donde sin duda pesará el que la administración busca la protección de un bien constitucionalmente defendido cual es el derecho a la vivienda, y se valorará la «buena fe» del deudor y las diferentes circunstancias que facilitaron u obligaron en la contratación. Sin duda, de inicio, ayudaría a descargar el sistema judicial. El recurso ante el TC radica en argumentar que la mediación se convierte en un obstáculo para el acceso a la justicia del acreedor que pretende reclamar, cuando es un medio de heterocomposición vigente desde la Ley 20/2014 del Parlamento de Cataluña (de modificación del Código de Consumo de Catalunya) que ya la introdujo en los casos de ejecución hipotecaria de la vivienda habitual, como mecanismo previo a cualquier otro procedimiento judicial o en la intervención notarial.

Cabe destacar el centrar la mira en la creación de un mercado de viviendas de coste social y de alquiler social que también debería ayudar, sobre todo en grandes urbes, a «controlar» el mercado inmobiliario, al combatirse la especulación agresiva (concreto comentario sobre los "grandes tenedores de vivienda») con la reversión del beneficio a la sociedad mediante expropiaciones temporales, la obligación del realojo en el parque no usado de los grandes operadores financieros, o la creación por la Administración de ayudas concretas limitadas en cantidad y tiempo para las familias en riesgo de exclusión (este aspecto es deseable pero de fino atine legislativo en su desarrollo).

El punto primordial, atendiendo a las amargas experiencias por la sistemática del «boom» inmobiliario de nuestro país, es la extensión de la exoneración, en materia de primera vivienda (no soy partidario en préstamos para otros fines, más evitables), a determinados deudores solidarios, fiadores y garantes hasta el tercer grado. Sin duda este punto per se hubiera hecho aconsejable en muchos supuestos acudir a estas leyes y no a la concursal, evitando sufrimientos más que cuestionables.

En consonancia, la lucha contra la «pobreza energética» es otro importante punto de avance; no en vano estamos en un país donde se ha llegado al absurdo de legislar en contra de las propias energías renovables y del autoconsumo.

No observo de gran valor el trato que hasta ahora se ha dado a la regulación de la ocupación de viviendas sin título habilitante, porque la falta de valentía lleva a no reconocer, como otras legislaciones 
que en otros conceptos hemos valorado como posible «espejo», que no es admisible, pero que la Administración debe operar en el ámbito de defensa del derecho a la vivienda no contrapuesto con el derecho a la propiedad privada (este último en paralelo con otros derechos sociales que ampararían el regular en materia que afectaría a los grandes operadores o a la propia Administración).

Y si el problema radica en que las Administraciones «periféricas» son acusadas de invadir competencias estatales, podemos analizar el propio Recurso ante el TC y sacar nuevas conclusiones, amén de las expuestas.

El artículo 2.1 de la Ley 24/2015 (que debo recordar no está suspendido en su vigencia) prevé expresamente que los consumidores en situación de sobreendeudamiento derivada de una relación de consumo, así como los acreedores, puedan solicitar un procedimiento, a menos que se encuentren inmersos en un procedimiento judicial concursal. La Ley 4/2016 no modifica en ningún momento esta disposición, que está plenamente vigente y no fue recurrida en su momento. Siendo invocado por el Gobierno el Dictamen del Consejo de Estado en su argumentación, que corresponde a la aprobación de la Ley 24/2015, ya indicaba que la mediación no debe ser obligatoria ni continuar cuando se haya iniciado el procedimiento de concurso de acreedores, lo que ha sido traspuesto a la regulación en la Ley 4/2016.

El Abogado del Estado defendió el mantenimiento de la suspensión en base a «...los perjuicios que habría de ocasionar el levantamiento de la suspensión de la vigencia de los preceptos impugnados, fundamenta sus alegaciones en los informes que adjunta a su escrito, del Ministerio de Economía y Competitividad de 1 de febrero de 2018 y del Banco de España de 13 de julio de 2017, los cuales consideran que las medidas controvertidas tienen un considerable impacto negativo sobre la situación financiera de las entidades bancarias, el crédito hipotecario, el mercado de cédulas hipotecarias y los compromisos internacionales asumidos por España, fundamentalmente en el memorando de entendimiento firmado el 20 de julio de 2012, y su seguimiento, en el marco de la ayuda financiera otorgada a nuestro país por la Unión Europea. ${ }^{51}$. ¡La influencia de los grandes operadores que impide avanzar en esta materia!. De hecho mantiene una férrea defensa del sistema concursal complementado con la Ley 25/2015, y el RDL 1/2015 en materia de segunda oportunidad. Defiende que la norma catalana se diferencia fundamentalmente de las estatales en

51 Escrito registrado ante el Tribunal Constitucional el día 5 de febrero de 2018. 
la estructura jurídica que soporta las medidas de protección. La normativa de ámbito nacional contempla la suspensión temporal de los procedimientos de ejecución, complementada con un esquema de adhesión voluntaria (código de buenas prácticas). Las normas autonómicas, por su parte, descansan en un procedimiento coercitivo. Y esa distinta articulación sólo puede dar lugar a conflictos, desde su postura inmovilista. Así «no se cuestiona, por tanto, que existan personas en situación de riesgo social que deban ser atendidas por los poderes públicos, pero ello debe efectuarse siempre dentro del marco constitucional de reparto de competencias y no interfiriendo las medidas adoptadas, como sucede con los preceptos cuya impugnación se ha instado».

El TC mantiene la suspensión del articulado sustantivo que es sustento de la efectividad de la norma y remite a continuar avanzando sin conflictos de leyes, aunque en apariencia el conflicto sea entre operadores financieros, Administración y Consumidor.

Bien sea por desarrollo de la propia LC, bien sea atemperando el conflicto, o bien pudiera ser recogiendo el guante de estas normas hoy recurridas, existe camino y el reflejo en Europa y el cumplimiento de las nuevas Directivas debe provocar avances que el consumidor español agradecerá. En dicho sentido se ha publicado la propuesta de Directiva 2016/0359 de 22 de noviembre de 2016 sobre marcos de reestructuración preventiva, segunda oportunidad y medidas para aumentar la eficacia de los procedimientos de condonación, insolvencia y reestructuración, y por la que se modifica la Directiva 2012/30/UE, que incide, dentro de este estudio, en materia de «segunda oportunidad» para empresarios personas físicas. Nuevamente el debate se centra en si no debería tratarse a todas las personas físicas y sólo distinguir entre créditos al consumo o empresariales (nuevamente la reforma no es completa, como lo demuestra el art. 23 de la Propuesta que a continuación abordamos). En este caso debemos tener presente que en lo relativo a la persona física no empresaria rige la Recomendación de la Comisión de 12 de marzo de 2014 sobre un nuevo enfoque frente a la insolvencia y el fracaso empresarial (2014/135/UE), que no obliga por la diferencia de trato y de período de exoneración de unos estados a otros. E indica que «la propuesta invita a los Estados miembros a ampliar la aplicación de los principios de aprobación de la gestión también a personas físicas que no sean empresarios, es decir, los consumidores. En los últimos años, muchos Estados miembros han adoptado o reformado las legislaciones nacionales en materia de insolvencia de los consumidores reconociendo la importancia de permitir que los consumidores puedan 
obtener una condonación de su deuda y merecer una segunda oportunidad. Sin embargo, no todos los Estados miembros disponen de tal legislación y los periodos de condonación de deudas en caso de sobreendeudamiento de los consumidores siguen siendo muy largos. Ayudar a los consumidores a reintegrarse en el ciclo de gasto es una parte importante del buen funcionamiento de los mercados y de los servicios financieros al por menor. La Comisión seguirá estudiando de qué manera los Estados miembros han reformado sus marcos nacionales y hará un seguimiento de cómo aplican esta disposición específica sobre segunda oportunidad recogida en la propuesta con el fin de revisar la situación de sobreendeudamiento de los consumidores.». Es como si el empresario persona física no tuviera préstamos no derivados de la actividad empresarial, y sin embargo, con esta nueva propuesta también podrían quedar saldados. En este sentido me parece más acertado nuestro actual art. 178 bis LC. Así señala el art. 1.3 «Los Estados miembros podrán ampliar la aplicación de los procedimientos contemplados en el apartado 1, letra b), al sobreendeudamiento de personas físicas que no sean empresarios.»(normas de reestructuración para empresarios sobreendeudados del art. 1.1.b)).

Realiza un tratamiento diferenciado del empresario persona física en su Título III. En su art. 20 regula plazos; acorta los plazos de exoneración indicando unos mínimos de 3 años (la LC establece 5 años), y siendo una regulación de mínimos, se debe completar con el ya comentado sistema de "segunda oportunidad ganada» (germano) regulado en el art. 21, marcándose el establecimiento de un plan de pagos ajustado a la realidad del empresario (buena conducta financiera). Debemos tener presente que nuestro art. 178 bis exige el pago de los créditos no exonerables para obtener la exoneración. El ajustarse a la realidad llevaría a la observancia de la imposibilidad de pago total.

Continúa la propuesta sin resolver la situación actual de los créditos no exonerables (de los créditos públicos o los de alimentos no dice nada y continúa no exonerable la vivienda garantía de préstamo), y sin embargo cita el interés general como leiv motiv para exonerar otras deudas, pero incluye tipos tan cuestionables como las derivadas de responsabilidad penal. Se centra en la protección de créditos derivados de la nueva reestructuración (art. 16 y 17) y de apoyo a la empresa o empresario.

Desde su publicación los estados miembros tendrán dos años para su adaptación. 


\section{BIBLIOGRAFÍA}

BOCG, Congreso de los Diputados.

CAPILla RonCERo, Francisco. «La responsabilidad patrimonial universal y el fortalecimiento de la protección del crédito, Fundación universitaria de Jerez, Cádiz, 1988.

Conclusiones del Seminario de Jueces de lo Mercantil y Juzgado de Primera InStancia NÚMERo 50 de BarCELONA, de 15 de junio de 2016.

Cuena Casas, Matilde, "A propósito del Real Decreto Ley 1/2015, de 27 de febrero, de mecanismo de segunda oportunidad, reducción de carga financiera y otras medidas de orden social», ElNotario.es, 30 de marzo de 2015 (revista digital)

Exposición de Motivos DE LA LEY 14/2013.

Fernández SeIJo, José M., «Aspectos Concursales de la Ley de Segunda Oportunidad», Diario La ley, n. ${ }^{\circ} 8500$, sección doctrina, 13 de marzo de 2015.

Fuenteseca Degenefe, «La condonación de deudas». Edit. Edersa, Madrid, 2003.

http://ep00.epimg.net/descargables/2014/07/10/2509f16067f17898 af32a70b8958b979.pdf

http://siteresources.worldbank.org/INTGILD/Resources/WB InsolvencyOfNaturalPersonsReport_01_11_13.pdf

https://europa.eu/european-union/eu-law/

https://www.eleconomista.es/

https://www.gouvernement.fr/

https://www.ine.es/

https://www.poderjudicial.es/

https://www.tribunalconstitucional.es/

Institut d’Estudis Autonòmics de Catalunya.

LASARTe, Carlos. «Derecho de Obligaciones. Principios de Derecho Civil II, 17.a ed., Marcial Pons, Madrid 2013,

Lasarte, Carlos. «Derecho de Obligaciones. Principios de Derecho Civil II», 17. ${ }^{\text {a }}$ ed., Marcial Pons, Madrid, 2013.

ORduÑa Moreno, «La insolvencia: análisis de su concepto y concreción de su régimen jurídico», Tirant Lo Blanch, Valencia, 1994. 
Pulgar Ezquerra, Juana, «Implicaciones concursales de la Ley 14/2013 de apoyo a los emprendedores y su internacionalización", Especial emprendedores, las leyes que los apoyan, Ed. La ley, Madrid 2013, aptdo. III-3 (www.laley.es).

RIBÓN SEISDEDOS, «El sobreendeudamiento en España: tutela judicial y protección legislativa», Informe realizado pro el CEACCU en diciembre de 2005.

Roca Sastre, Ramón M. a y Puig Brutau, José. «Estudios de Derecho privado», Volumen I, Aranzadi, Madrid, 2009.

RoJo, Ángel, «La reforma del derecho concursal español» (Rojo, dr.), Ed. Marcial Pons, Madrid-Barcelona, 2003.

SENÉs, Carmen, «La homologación de los acuerdos de refinanciación, ADCo, núm. 30 (septiembre-diciembre), 2013, comentado en Revista de derecho Civil, vol. I, núm. 1 Estudios.

SERRANo GómEz, Eduardo y otros, "Sistemas de tratamiento de la insolvencia de la persona física», CuEna CASAS, Matilde (dra.), en Familia y Concurso de Acreedores, Thomson Reuters (Aranzadi), Pamplona, 2010.

SuÁrez-Llanos GómEZ, «El presupuesto objetivo del concurso: el estado de insolvencia». Las claves de la Ley concursal, Navarra, Aranzadi, 2005 (Dr. Quintana Carlos, Bonet Navarro, GarciaCRUCE GonZÁLEZ).

Viguer Soler, P.L., «Análisis crítico del RDL 1/2015 sobre "segunda oportunidad": expectativas, luces y sombras», Diario La Ley n. ${ }^{\circ}$ 8592, Sección Doctrina, 29-07-2015, Ref. D-304 (LA LEY $5003 / 2015)$.

Zabaleta DíAZ, «La condonación de las deudas pendientes en el Derecho Concursal Alemán», AA.VV., Estudios sobre la Ley Concursal. Libro Homenaje a Manuel Olivencia, Tomo I, Madrid 2005.

Nota. Las páginas y sitios de internet fueron revisados nuevamente para cerrar el trabajo el día 09.06.2018. 
